"Manual for the Care and Maintenance of the Bristol Jupiter Aero Engine. Series VI." The Bristol Aeroplane Company, Limited.

"Flying for Air Survey Photography," by F. Tymms and C. Porri.

R. \& M., No. I,05o. Reports and Memoranda of the Aeronautical Research Committee published between the Ist January, 1925, and the 28th February, 1927.

\title{
Leeds Branch
}

The President of the Society, Air Vice-Marshal Sir Sefton Brancker, has consented to deliver the inaugural lecture of the Session arranged by the Leeds Branch of the Royal Aeronautical Society. The lecture will take place on October $25^{\text {th. }}$

\section{Associate Fellowship Examination}

Provided that a sufficient number of entries is received, the Society's examination for candidates otherwise not qualified for Associate Fellowship will be held during the third week of September. Intending candidates should forward their entry forms as soon as possible and in any case before the third week of August.

\section{J. Laurence Pritchard, Secretary.}

\section{OB I T UARY}

\section{Colonel John Davidson Fullerton}

It is with very great regret that the Council have to record the death of Colonel J. D. Fullerton, who died on June 17 th, 1927 .

Colonel Fullerton, who was the son of Lieutenant James Fullerton, of the 16 th Bengal. Native Infantry, was born in India on July $13^{\text {th, }}$, I853, and educated at Cheltenham and the Royal Military Academy, Woolwich. He served in the Afghan. War (1879-80) and in the Burmese Expedition $(1885-87)$ and was four times mentioned in despatches. He retired in 1905 with the rank of Colonel.

Colonel Fullerton always took the liveliest interest in aeronautics and was on the Council of the Society for many years, and for two years its Honorary Secretary. During the period he was Honorary Secretary the Society passed through a difficult and critical time and Colonel Fullerton put in an immense amount of good work, helping to place the Society on a sound footing. 